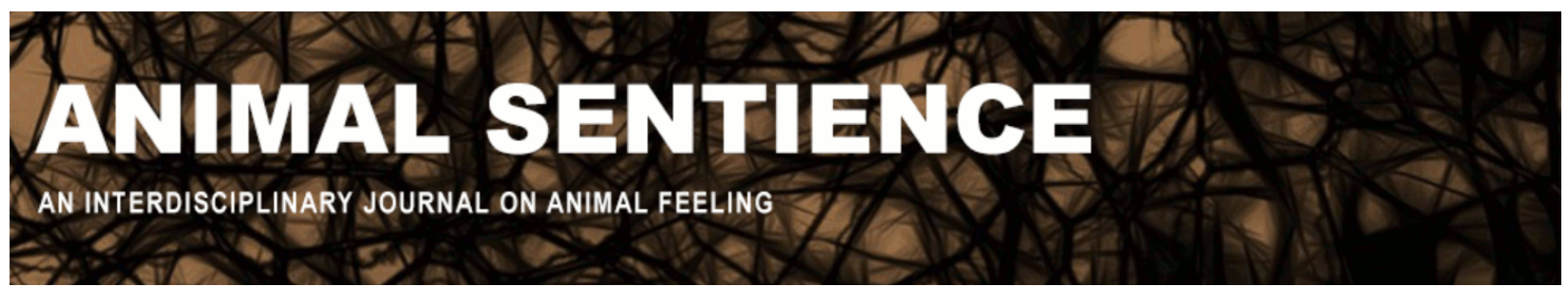

Colombo, Matteo (2016) Animal grieving and human mourning. Animal Sentience $4(10)$

DOI: $10.51291 / 2377-7478.1133$

Date of submission: 2016-08-04

Date of acceptance: 2016-08-06

(c)

This article has appeared in the journal Animal

Sentience, a peer-reviewed journal on animal

cognition and feeling. It has been made open access,

free for all, by WellBeing International and deposited

in the WBI Studies Repository. For more information,

please contact

wbisr-info@wellbeingintl.org.

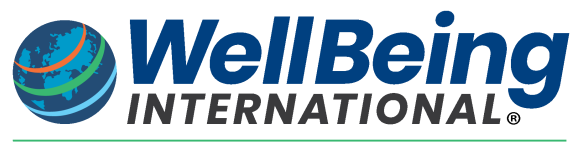

SOLUTIONS FOR PEOPLE, ANIMALS AND ENVIRONMENT 


\title{
Animal grieving and human mourning
}

Commentary on King on Animal Grief

\author{
Matteo Colombo \\ Tilburg Center for Logic, Ethics and Philosophy of Science \\ Tilburg University, Netherlands
}

\begin{abstract}
King's How animals grieve beautifully describes several ways in which animals and humans show a similar capacity for grief. Yet this book does not sufficiently emphasise the language-empowered capacity to objectify thinking and sentiments about death, which makes human mourning unique. Here I put this capacity into focus and relate it to the socialnormative aspect of human mourning that seems to be missing in other animals.
\end{abstract}
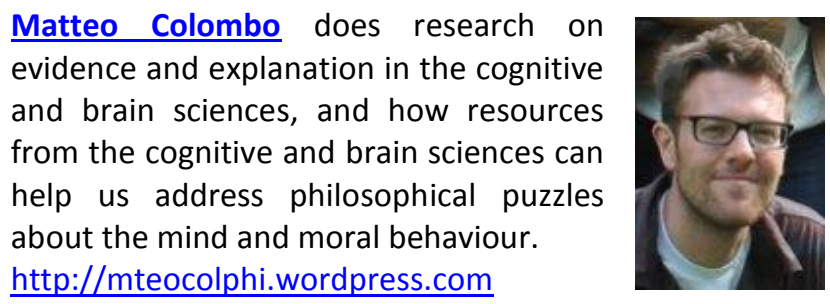

The central claim of Barbara King's (2013) How animals grieve is that a "variety of highly social birds and mammals show the capacity for grief ... and individual animals from these species mourn because they've felt love for another creature" (p. 154). While humans and many other animals would be alike in this respect, King suggests that human grief may be unique in our ability "to fully anticipate the inevitability of death ... and to express our losses in a thousand glorious or ragged ways" (p. 7). In what follows I would like to elaborate on King's suggestion and to highlight one aspect that goes neglected in her discussion: the distinctive social-normative dimension of human mourning.

How animals grieve focuses on animal grief as an individual experience grounded in the bereaved's emotional bond with the deceased. King defines grief in terms of significant deviations from usual routines displayed by survivors after the death of a significant companion animal (p. 163). She does not distinguish grief from mourning.

At least in humans, however, mourning is distinctively different from grief. Mourning is bound up with a complex web of social norms in humans. The way humans experience a beloved's death and the way we humans express our feelings of loss are governed by complicated patterns of mutual expectations grounded in social norms.

Across time and place, people express their mourning by wearing black clothes. Necrologies display how people's experience of death mirrors societal values. Mortuary aphorisms mark what is socially appropriate to say and to think about the dead, which, in turn, influences individual experiences of grief. Pericles's funeral oration reported in Thucydides's History of the Peloponnesian War, Plato's Menexenus, as well as many other mourning texts, paintings, and statues in many different traditions and cultures highlight that human mourning has ineliminable social aspects. 
In her Précis to How animals grieve, King (2016) explains that "our mourning rituals ... are comparatively elaborated in symbolic ways, not because we are the only cultural animals, but because our culture developed along a trajectory that puts a premium on community-, language- and technology-based responses to death" (p. 4). The right way of understanding King's explanation, I believe, should not focus on community and technology. Rather, it is the language-empowered capacity to objectify our thinking and sentiments about death that makes human mourning unique, infusing it with a social-normative aspect that is missing in other animals.

"To formulate a thought in words (or on paper) is to create an object available to ourselves and to others and, as an object, it is the kind of thing we can have thoughts about"(Clark 2006, p. 372). Linguistic formulations of thoughts and experiences following somebody's death create the conditions for a kind of mourning that is distinct from individual experiences of grief.

Non-human animals' experience of grief can have only local effects, which are beautifully described by King's How animals grieve. The human experience of grief, courtesy of language, can instead spread throughout space and time by creating cognitive niches that foster a normative explosion that governs our mourning practices. Such niches correspond to social structures such as families, churches, legal systems, hospitals, schools, museums, theatres and so forth. In such niches, norms governing mourning get propagated and become themselves objects of thinking (Colombo 2013).

Churches, schools, and museums ensure that certain norms of mourning are passed on to future generations. They also provide us with conditions to bring normative considerations to bear on these norms themselves. Social structures like churches, schools and museums are niches where individual and collective thinking of grief can be objectified, thereby promoting a normative explosion where new norms can emerge to shape our experience of death.

Humans can manage and direct such complex social structures only because language enables us to compose and reflect on necrologies, death aphorisms, maxims, labels, and moral summaries; language enables us to make normative considerations, which bear on the social norms of mourning. Thus we can manage such social structures so as to facilitate the attainment of determinate effects on the community as a whole - just think about the effects of Pericles's funeral oration on the Athenians. Although language does not constitute a domain of grieving, it dramatically changes its scope. Language is constitutive of the social practice of mourning, as it enables and fosters local effects of individual grief to spread systemically and reiteratively across space and time. While non-human animals can grieve, non-human animals might not be able to engage in the distinctively social practice of mourning.

\section{References}

Clark, A. (2006) Language embodiment and the cognitive niche. Trends in Cognitive Sciences, $10,370-374$.

Colombo, M. (2013). Leges sine moribus vanae: Does language make moral thinking possible?. Biology \& Philosophy, 28(3), 501-521.

King, B. J. (2013). How animals grieve. Chicago, IL: University of Chicago Press.

King, B. J. (2016). Animal mourning: Précis of How animals grieve (King 2013). Animal Sentience 2016.004. 